\title{
Integrated use of farm manure and synthetic nitrogen fertilizer improves nitrogen use efficiency, yield and grain quality in wheat
}

\author{
Abdur Rehim, ${ }^{1}$ Maryam Khan, ${ }^{1}$ Muhammad Imran, ${ }^{1,2}$ Muhammad Amjad Bashir, ${ }^{1}$ \\ Sami Ul-Allah, ${ }^{3}$ Muhammad Naeem Khan, ${ }^{4}$ Mubshar Hussain ${ }^{5,6}$ \\ ${ }^{1}$ Department of Soil Science, Bahauddin Zakariya University, Multan, Pakistan; ${ }^{2}$ Soil and Water Testing \\ Laboratory, Khanewal, Pakistan; ${ }^{3}$ College of Agriculture, BZU Sub Campus, Layyah, Pakistan; ${ }^{4}$ Directorate \\ General Soil Survey of Punjab, Agriculture Department, Lahore, Pakistan; ${ }^{5}$ Department of Agronomy, \\ Bahauddin Zakariya University, Multan, Pakistan; ${ }^{6}$ School of Veterinary and Life Sciences, Murdoch \\ University, Murdoch, WA, Australia
}

\begin{abstract}
Lower nitrogen use efficiency (NUE) is a major yield limiting factor in semi-arid regions due to poor organic contents of the soils. There is a close relationship between soil organic matter and NUE of fertilizers. Therefore, this study was conducted to assess the effect of sole $\mathrm{N}$ fertilizer and its combinations with organic amendments (farm manure combinations) on $\mathrm{N}$ use efficiency and crop productivity. For this purpose, a two-year field study was conducted to access the influence of integrated use of synthetic $\mathrm{N}$ fertilizer (urea) and farm manure on $\mathrm{N}$ use efficiency and wheat productivity. Treatments include i.e. Control, $100 \% \mathrm{~N}$ by Urea + $0 \% \mathrm{~N}$ by farm manure (FM), $75 \% \mathrm{~N}$ by Urea $+25 \% \mathrm{~N}$ by $\mathrm{FM}$, $50 \% \mathrm{~N}$ by Urea $+50 \% \mathrm{~N}$ by FM, $25 \% \mathrm{~N}$ by Urea $+75 \% \mathrm{~N}$ by FM, $0 \% \mathrm{~N}$ by Urea $+100 \% \mathrm{~N}$ by FM arranged in a triplicate randomized complete block design having recommended $N$ rate of $150 \mathrm{~kg}$ $\mathrm{ha}^{-1}$. The results revealed that the treatment having 75\% Urea and $25 \%$ FM followed by $50 \%$ Urea and $50 \%$ FM showed better results in term of wheat growth and yield. There was $98 \%$ increase in $\mathrm{N}$ uptake of wheat grains and $200 \%$ increase in NUE by the application of $75 \%$ urea $+25 \%$ FM relative to sole application of urea. This study suggests use of 3:1 ratio of urea and FM for maximum NUE and sustainable wheat production.
\end{abstract}

Correspondence: Mubshar Hussain, Department of Agronomy, Bahauddin Zakariya University, Multan, Pakistan; and School of Veterinary and Life Sciences, Murdoch University, 90 South Street, Murdoch, WA 6150, Australia.

E-mail: mubashiragr@gmail.com

Key words: Wheat; urea; farm manure; yield and grains quality parameters.

Received for publication: 18 November 2018.

Revision received: 26 August 2019.

Accepted for publication: 10 September 2019.

(C) Copyright: the Author(s), 2020

Licensee PAGEPress, Italy

Italian Journal of Agronomy 2020; 15:1360

doi:10.4081/ija.2020.1360

This article is distributed under the terms of the Creative Commons Attribution Noncommercial License (by-nc 4.0) which permits any noncommercial use, distribution, and reproduction in any medium, provided the original author(s) and source are credited.

\section{Introduction}

Soil conditions are conducive for less fertilizer use efficiency and their higher losses, especially volatilization losses of urea fertilizers due to soil alkalinity and low organic matter. Moreover, soil degradation due to rapid increase in population and urbanization, lack of quality seed, erratic rainfall, drought and changing climate have led to food insecurity in developing countries, especially in Pakistan (Ul-Allah et al., 2014; Abid et al., 2016; Hussain et al., 2018). In this scenario, there is dire need to develop new agronomic approaches to improve fertilizer use efficiency and to reduce $\mathrm{N}$ losses by leaching and volatilization for sustainable agriculture. The use of animal manure is a potential organic amendment to enhance the soil fertility and to increase the efficient use of inorganic fertilizers by plants. Wheat (Triticum aestivum L.) is the most important cereal crop all around the world but grain yield of wheat declines due to weed problem, poor condition of soils, low quality seeds, late harvesting and planting, imbalance application of fertilizers and shortage of irrigation water (Timsina and Connor, 2001; Hussain et al., 2012, 2016; Ul-Allah et al., 2018).

Nitrogen is one of the most important mineral nutrients for the growth of wheat crop. It is an important constituent of living tissues of all plants and comprises about $1.4 \%$ of their dry weight and thus is highly effective in promoting plant growth and protein content. As the $\mathrm{N}$ contents in plant tissue increases, it improves chlorophyll contents and leaf areas, resulting in the more carbohydrate production in plants which correspond to the more gluten proteins in wheat grains (Godfrey et al., 2010). The processing properties of wheat dough are greatly influenced by gluten protein contents of wheat grains by conferring visco-elasticity (Khan et al., 2001). Therefore along with yield, grain nutritional quality is also very important to ensure sustainable food security.

Improvement in crop production by the use of inorganic fertilizers alone has negative impact on the soil fertility. However, both inorganic and organic fertilizers (farm yard manure) improve soil structure, water and nutrient holding capacities of the soil, better root penetration in the soil, soil microorganism activities, nutrient exchange capacity and thus increase the soil fertility (Yazdanpanah et al., 2016; Zhao et al., 2016). Sarwar (2005) reported that growth and yield of rice and wheat plants was improved by the combined application of inorganic and organic fertilizers as compared to chemical fertilizers alone. The use of farmyard manure is preferred on other organic fertilizer sources because its shorter decomposition period compares to others organic sources of nutrients (Chupora, 1995). However, FM cannot satisfy the nutrient requirements of high yielding crops 
(Satyanarayana et al., 2002). Integration of inorganic and organic fertilizers is the best strategy to increase the soil fertility and thus to obtain high crop yields (Bedada et al., 2014; Rehim et al., 2016). The combine application of FM along with urea not only increases the efficiency of both organic and inorganic source but it is also more economical for the users as inorganic fertilizers (Hussain et al., 2018).

Beneficial effects of combine application of FM and inorganic fertilizers are well documented, but best combination of FM with organic fertilizer to ensure maximum productivity, nutritional quality and NUE is not well understood. Therefore, main objective of the study was to identify the best combination of FM and inorganic fertilizer for sustainable wheat production with maximum productivity, nutritional quality and NUE.

\section{Materials and methods}

\section{Brief description of experimental site}

A two-year field experiment was (2010-11 and 2011-12) was conducted at the Agricultural Research Area of the Faculty of Agricultural Sciences and Technology, Bahauddin Zakariya University, Multan, Pakistan $\left(71.43^{\circ} \mathrm{E}, 30.2^{\circ} \mathrm{N}\right.$ and $122 \mathrm{~m}$ above sea level). Before sowing, composite soil samples $(0-15$ and $15-30 \mathrm{~cm}$ depth) were analyzed for the determination of soil physical and chemical characteristics (Table 1; Richards, 1954). Weather data of experimental site during both years of study is presented in Figure 1.

\section{Experimental details}

Analysis indicated that farm manure (FM) used in the experiment had $0.98,0.25$ and $0.62 \%$ of $\mathrm{N}$, phosphorus $(\mathrm{P})$ and potassium $(\mathrm{K})$, respectively. Seeds of wheat cultivar "Seher-2006" were obtained from Ayub Agricultural Research Institute (AARI), Faisalabad and used as experimental material. Experiment consisted on six treatments viz. $\mathrm{T}_{1}=$ Control (no application of urea or $\mathrm{FM}) ; \mathrm{T}_{2}=$ Recommended $\mathrm{N}$ by urea; $\mathrm{T}_{3}=75 \%$ of recommended $\mathrm{N}$ by urea $+25 \% \mathrm{~N}$ by $\mathrm{FM} ; \mathrm{T}_{4}=50 \%$ of recommended $\mathrm{N}$ by urea + $50 \% \mathrm{~N}$ by FM; $\mathrm{T}_{5}=25 \%$ recommended $\mathrm{N}$ by urea $+75 \% \mathrm{~N}$ by $\mathrm{FM}$; $\mathrm{T}_{6}=100 \% \mathrm{~N}$ by FM taking $150 \mathrm{~kg} \mathrm{~N} \mathrm{ha}^{-1}$ as recommended dose. The experiment was laid out following randomized complete block design (RCBD) with three replications and net plot size of $6 \mathrm{~m} \times$ $2.7 \mathrm{~m}$. Urea was applied in two splits, half at the time of sowing and remaining half with first irrigation while whole FM was incorporated at the time of sowing.

\section{Crop husbandry}

A pre-soaking irrigation of about $10 \mathrm{~cm}$ depth was applied to create conditions more conducive for wheat sowing. After achieving workable moisture contents, the seedbed was prepared by cultivating the field twice followed by planking. Wheat was sown on $10^{\text {th }}$ and $12^{\text {th }}$ of November during 2010-2011 and 2011-12 respectively. Sowing was done with single row hand drill in $22.5 \mathrm{~cm}$ spaced rows by using seed rate of $125 \mathrm{~kg} \mathrm{ha}^{-1}$. Fertilizers were applied at the rate of 150,125 and $100 \mathrm{~kg}$ of NPK ha- ${ }^{-1}$ Nitrogen was applied according to treatments. Remaining total amount of $\mathrm{P}$ and $\mathrm{K}$ were applied at sowing as triple super phosphate and sulfate of potash respectively after deducting the amount of $\mathrm{P}$ and $\mathrm{K}$ present in FM already added in respective plots according to treatments. Weeds were controlled manually. In total, four irrigations were given in both years to avoid moisture stress.

\section{Data recorded}

Crop was harvested at harvest maturity on $18^{\text {th }}$ and $22^{\text {nd }}$ of April during 2011 and 2012. Data of yield traits i.e. population of productive tillers $\left(\mathrm{m}^{-2}\right)$, number of grains per spike and 1000-grain weight (g) were recorded as described by Hussain et al. (2016). Plant height from base to tip of spike of twenty random selected tillers from each plot was recorded and averaged to record plant height. Whole plots were harvested and manually threshed after drying as to record grain and straw yield ha ${ }^{-1}$ following Hussain et al. (2016). Sub-samples of straw and grains were collected from each plot. Straw samples were washed with distilled water followed by drying with tissue papers before oven drying to a constant weight at $65^{\circ} \mathrm{C}$. Then, these samples were ground to pass a $1 \mathrm{~mm}$ sieve in a grind mill (IKA Werke, MF 10 Basic, Staufen, Germany). Grounded subsamples of known weights were wet-digested in a di-acid mixture $\left(\mathrm{HNO}_{3}\right.$ : $\mathrm{HClO}_{4}$, ratio 2:1; Jones and Case, 1990). The $\mathrm{N}$ contents of each sample of seeds and straw were determined by using micro Kjeldahal method (Jackson, 1962). Nitrogen use efficiency (NUE) was calculated by using the formula described by Fageria et al. (1997).

NUE(\%)

TotalNUptakeinfertilizedPlot $\left(\mathrm{kgha}^{-1}\right)-$ TotalNUptakeinunfertilizedPlot $\left(\mathrm{kgha}^{-1}\right)$

$\times 100 \quad$ Nuptakebyseed $\left(\mathrm{kgha}^{-1}\right)=\frac{\text { Nconcentrationinseed }(\%) \times \text { Yield }\left(\mathrm{kgha}^{-1}\right)}{100}$

Table 1. Physico-chemical properties of soil used in experiment.

\begin{tabular}{lcc} 
Soil property & Units & Value \\
Textural class & - & Silty clay loam \\
$\mathrm{pH}_{\mathrm{s}}$ & - & 8.5 \\
\hline $\mathrm{EC}_{\mathrm{e}}$ & $\mathrm{dS} \mathrm{m}^{-1}$ & 2.69 \\
Calcium Carbonate & $\%$ & 7.90 \\
\hline Organic Matter & $\%$ & 0.78 \\
Total N & $\%$ & 0.038 \\
\hline Available P & $\mathrm{mg} \mathrm{kg}^{-1}$ & 11 \\
Extractable K & $\mathrm{mg} \mathrm{kg}^{-1}$ & 240 \\
\hline
\end{tabular}

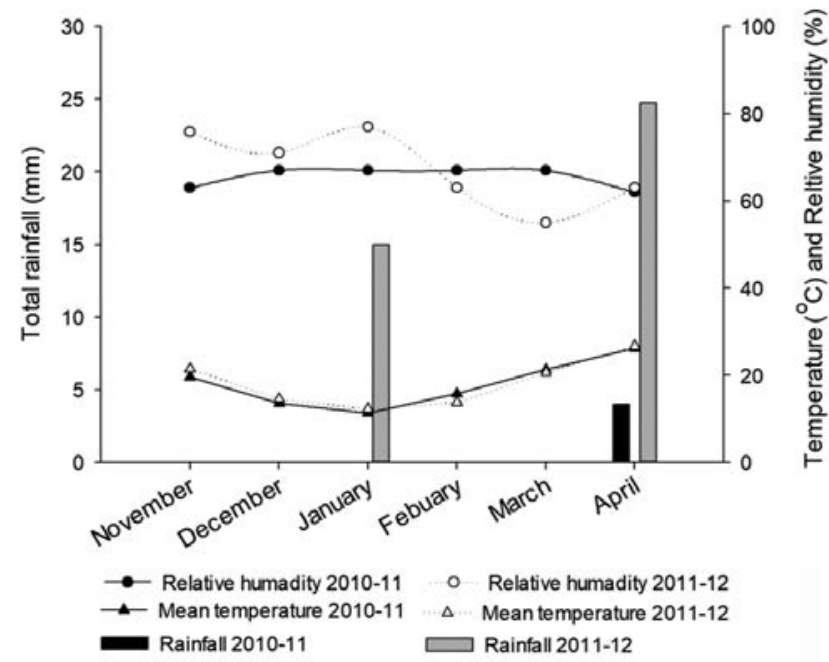

Figure 1. Weather data of the experimental location during the experiment of 2010-11 and 2011-12. 


\section{Quality parameters}

The total protein percentage was calculated by the method of Chapman and Parker (1961):

TotalProtein $(\%)=$ TotalNitrogen $(\%) \times 6.25$

The starch content and dry gluten content of wheat grain were determined by using the standard procedure described in AACC (2000).

\section{Economic analysis}

To conduct economic analysis, total cost of production and total income was calculated. To estimate total expenses, cost of all inputs and husbandry practices (cost of land preparation, seed, sowing, fertilizers, FM, irrigation, insect pests and disease management, harvesting, threshing and land rent) according to prevailing market rates was used. The gross income was calculated by multiplying the total grain and straw yields with unit price of wheat grains and straw in local market. The net returns were calculated by subtracting the total cost from gross income. The benefit-cost ratio was calculated by dividing the gross income by total cost.

\section{Statistical analysis}

Analysis of variance (ANOVA) was based on RCBD and treatment were ranked by least significant difference (LSD) test at $\mathrm{P} \leq 0.05$ (Steel and Torrie, 1997). Various statistical computations were run on Statistix $9^{\circledR}$ for Windows (Analytical Software, Tallahassee, USA).

\section{Results}

\section{Agronomic and yield related traits}

Plant height responded significantly $(\mathrm{P} \leq 0.05)$ to different urea and FM combinations and it ranged from 81.21 to $98.37 \mathrm{~cm}$ and
81.26 to $98.42 \mathrm{~cm}$ during years of 2010-2011 and 2011-2012, respectively (Table 2). However, maximum increase in plant height was $21 \%$ by the application of $75 \%$ urea $+25 \% \mathrm{FM}$ followed by $17.6 \%$ with $50 \%$ urea $+50 \%$ FM and $16.2 \%$ with $25 \%$ urea $+75 \%$ FM over control approximately in both years. However, minimum increase of $6.4 \%$ in plant height was recorded when source of $\mathrm{N}$ was only FM (Table 2). Different urea and FM combinations had significant effect on population of productive tillers and number of grains per spike of wheat in both years of study (Table 2). Treatments receiving 50\% urea $+50 \%$ FM and $75 \%$ urea $+25 \%$ FM gave best results for both years of study. Likewise, maximum increase in number of grains per spike in both years was $40 \%$ by the application of $75 \%$ urea $+25 \%$ FM followed by $36 \%$ and $34 \%$ by with $50 \%$ urea $+50 \% \mathrm{FM}$ and $25 \%$ urea $+75 \% \mathrm{FM}$ over control, respectively (Table 2). Different combinations of urea and FM had significant effect on 1000-grain weight, grain yield and straw yield of wheat in both years of study (Table 3 ). There was maximum increase of about $13 \%$ in 1000 -grain weight by the application of $75 \%$ urea $+25 \% \mathrm{FM}$ and $12 \%$ increase by the addition of $50 \%$ urea $+50 \%$ FM as compared to control treatment in years of 2010-11 and 2011-12, respectively. The grain yield of wheat ranged from 3.12-4.92 $\mathrm{Mg} \mathrm{ha}^{-1}$ and 3.13-4.94 $\mathrm{Mg} \mathrm{ha}^{-1}$ during the years 2010-11 and 2011-12, respectively. The treatments significantly differed in terms of grain yield; however $\mathrm{N}$ application in combination of $75 \%$ urea $+25 \% \mathrm{FM}$ harvested the highest grain yield of 4.92 and $4.94 \mathrm{Mg} \mathrm{ha}^{-1}$ during 201011 and 2011-2012, respectively compared with all other treatments (Table 3). Almost similar trend was observed for straw yield in both years of study (Table 3). Better yield attributes were obtained by the combination of FM with inorganic fertilizer (urea) in the ratio of 75:25 and 50:50 as compared to all other treatments.

\section{Nitrogen in plants}

Different combinations urea and FM showed significant $(\mathrm{P} \leq 0.05)$ effect on the $\mathrm{N}$ concentration in wheat grains and straw for both years of study (Table 4). Nitrogen concentration in wheat

Table 2. Effect of different combinations of farm manure and urea on plant height, number of tillers and number of grains/spike of wheat.

\begin{tabular}{|c|c|c|c|c|c|c|}
\hline \multirow[t]{2}{*}{ Treatments } & \multicolumn{2}{|c|}{ Plant height (cm) } & \multicolumn{2}{|c|}{ Number of tillers $\left(\mathrm{m}^{-2}\right)$} & \multicolumn{2}{|c|}{ Number of grains/spikt } \\
\hline & 2010-11 & 2011-12 & 2010-11 & 2011-12 & 2010-11 & 2011-12 \\
\hline $0 \%$ urea $+0 \%$ FM & $81.21^{\mathrm{e}}$ & $81.26 \mathrm{e}$ & $159.00^{\mathrm{d}}$ & $161.00^{\mathrm{d}}$ & $32.35^{\mathrm{e}}$ & $32.41^{\mathrm{e}}$ \\
\hline $100 \%$ urea $+0 \%$ FM & $92.67^{\mathrm{c}}$ & $92.71^{\mathrm{c}}$ & $226.67^{c}$ & $228.33^{c}$ & $41.44^{c}$ & $41.45^{\mathrm{c}}$ \\
\hline $75 \%$ urea + 25\% FM & $98.37^{\mathrm{a}}$ & $98.42^{\mathrm{a}}$ & $275.00^{\mathrm{a}}$ & $277.33^{\mathrm{a}}$ & $45.33^{\mathrm{a}}$ & $45.38^{\mathrm{a}}$ \\
\hline $50 \%$ urea $+50 \%$ FM & $95.49^{\mathrm{b}}$ & $95.53^{b}$ & $278.67^{\mathrm{a}}$ & $280.00^{\mathrm{a}}$ & $44.10^{\mathrm{ab}}$ & $44.15^{\mathrm{ab}}$ \\
\hline $25 \%$ urea $+75 \%$ FM & $94.35^{\mathrm{bc}}$ & $94.40^{\mathrm{bc}}$ & $262.33^{\mathrm{b}}$ & $264.00^{b}$ & $43.45^{b}$ & $43.49^{b}$ \\
\hline $0 \%$ urea + 100\% FM & $86.39^{\mathrm{d}}$ & $86.45^{\mathrm{d}}$ & $143.67^{\mathrm{e}}$ & $144.67^{\mathrm{e}}$ & $34.47^{\mathrm{d}}$ & $34.51^{\mathrm{d}}$ \\
\hline
\end{tabular}

$\mathrm{FM}$, farm manure. a- ${ }^{\text {-e }}$ ifferent letters in the same column indicate significant differences by least significant difference test at $P \leq 0.05$.

Table 3. Effect of different combinations of farm manure and urea application on yield and related traits of wheat.

\begin{tabular}{|c|c|c|c|c|c|c|}
\hline Treatments & 1000-g1 & eight (g) & Grain y' & Yg $\left.h a^{-1}\right)$ & Straw y & $\left(\mathrm{Mg} \mathrm{ha} \mathrm{a}^{-1}\right)$ \\
\hline & $2010-11$ & $2011-12$ & $2010-11$ & $2011-12$ & $2010-11$ & $2011-12$ \\
\hline $0 \%$ urea $+0 \%$ FM & $40.76^{\mathrm{d}}$ & $40.78^{d}$ & $3.12^{\mathrm{f}}$ & $3.13^{f}$ & $6.74^{c}$ & $6.22^{\mathrm{f}}$ \\
\hline $100 \%$ urea $+0 \%$ FM & $44.82^{b}$ & $44.21^{b}$ & $3.60^{\mathrm{d}}$ & $3.61^{\mathrm{d}}$ & $7.58^{\mathrm{ab}}$ & $6.94^{c}$ \\
\hline $75 \%$ urea $+25 \%$ FM & $46.03^{a}$ & $46.08^{a}$ & $4.92^{\mathrm{a}}$ & $4.94^{\mathrm{a}}$ & $7.95^{\mathrm{a}}$ & $8.09^{a}$ \\
\hline $50 \%$ urea $+50 \%$ FM & $45.65^{\mathrm{ab}}$ & $45.69^{\mathrm{a}}$ & $4.09^{b}$ & $4.11^{b}$ & $7.66^{\mathrm{ab}}$ & $7.14^{b}$ \\
\hline $25 \%$ urea $+75 \%$ FM & $44.81^{b}$ & $44.85^{b}$ & $3.94^{\mathrm{c}}$ & $3.95^{\mathrm{c}}$ & $7.2^{\mathrm{bc}}$ & $6.67^{d}$ \\
\hline $0 \%$ urea $+100 \%$ FM & $42.24^{c}$ & $42.28^{\mathrm{c}}$ & $3.45^{\mathrm{e}}$ & $3.46^{\mathrm{e}}$ & $7.02^{c}$ & $6.49^{\mathrm{e}}$ \\
\hline
\end{tabular}

FM, farm manure. ${ }^{\text {a-f }}$ Different letters in the same column indicate significant differences by least significant difference test at $\mathrm{P} \leq 0.05$. 
grains ranged from $1.47-1.91 \%$ and $1.48-1.93 \%$ in years $2010-11$ and 2011-12, respectively over all the treatments. While its concentration in wheat straw ranged from $0.27-0.57 \%$ in $2010-11$ and $0.29-0.59 \%$ in $2011-12$ respectively, over all the treatments. Nitrogen concentration in the grain and straw was enhanced by the combined application of organic and inorganic sources of Nitrogen compared with their addition to soil alone and control treatment. Highest values of grain and straw nitrogen concentrations were recoded with urea $75 \%+$ FM $25 \%$ in both years of study. There were significant differences among treatments with respect to nitrogen uptake by grain and nitrogen concentration in straw in both years (Table 4). For both years, farm yard manure providing $25 \%$, $50 \%$ and $75 \%$ of available nitrogen used in combination with urea fertilizers resulted in average increase in $\mathrm{N}$ uptake by $62 \%, 23 \%$, and $10 \%$ in the grain compared to sole application of urea, while by $74 \%, 32 \%$ and $18 \%$ increase in the grain nitrogen content compared to sole application of FM (Table 4). Urea and FM treatments significantly affected NUE and maximum was obtained when urea and FM were in 75:25 combinations. Similarly, NUE with sole urea was higher compared to sole FM application. NUE with 75:25 urea, FM combination was approximately 200 and $450 \%$ higher than sole application of urea and FM respectively in both years.

\section{Quality parameters}

In present study quality traits i.e. protein contents, starch contents and gluten contents were also significantly $(\mathrm{P} \leq 0.05)$ effected by different urea and FM combinations for the both years (Table 5). Maximum average increase in protein contents were about $30 \%$ by the application of $75 \%$ urea $25 \%$ FM compared with control treatment. Maximum grain starch contents of $55.40 \%$ and $55.41 \%$ obtained by the application of $75 \%$ urea $+25 \%$ FM during the year 2010-11 and 2011-12 respectively (Table 5). Like protein and starch contents, during both years' maximum and minimum gluten contents were produced with treatment $75 \%$ urea $+25 \%$ FM and un-amended control, respectively.

\section{Economic analysis}

Economic analysis compared different treatments for their total expenses, gross income and net profit. Based on cost benefit ratio (BCR), combination of 75:25 urea, FM combination proved best as its BCR value is 1.45 followed by 50:50 urea, FM combination where BCR value is 1.22 . Thus, treatment with 75:25 urea, FM combination is most profitable for the farmers (Table 6)

Table 4. Effect of different combinations of farm manure and urea on $\mathrm{N}$ uptake and $\mathrm{N}$ use efficiency of wheat.

\begin{tabular}{|c|c|c|c|c|c|c|c|c|}
\hline Treatments & N c & rains & $\mathbf{N}$ col & raw & N upt & grains & Nitrogen & ficiency \\
\hline $0 \%$ urea $+0 \% \mathrm{FM}$ & $1.47^{\mathrm{e}}$ & $1.48^{\mathrm{e}}$ & $0.27^{\mathrm{e}}$ & $0.29 \mathrm{e}$ & $46.02^{\mathrm{f}}$ & $46.04^{\mathrm{f}}$ & $0.00^{f}$ & $0.00^{f}$ \\
\hline $100 \%$ urea + 0\% FM & $1.62^{c}$ & $1.63^{\mathrm{c}}$ & $0.39^{c}$ & $0.40^{c}$ & $58.32^{\mathrm{d}}$ & $58.34^{\mathrm{d}}$ & $16.33^{\mathrm{d}}$ & $16.35^{\mathrm{d}}$ \\
\hline $75 \%$ urea $+25 \%$ FM & $1.91^{\mathrm{a}}$ & $1.93^{\mathrm{a}}$ & $0.57^{\mathrm{a}}$ & $0.59^{a}$ & $94.19^{\mathrm{a}}$ & $94.22^{\mathrm{a}}$ & $50.35^{\mathrm{a}}$ & $50.37^{a}$ \\
\hline $50 \%$ urea $+50 \%$ FM & $1.75^{b}$ & $1.78^{b}$ & $0.57^{a}$ & $0.59^{\mathrm{a}}$ & $71.77^{\mathrm{b}}$ & $71.79^{b}$ & $33.71^{b}$ & $33.72^{\mathrm{b}}$ \\
\hline $25 \%$ urea $+75 \%$ FM & $1.63^{\mathrm{c}}$ & $1.64^{\mathrm{c}}$ & $0.48^{b}$ & $0.50^{\mathrm{b}}$ & $64.31^{\mathrm{c}}$ & $64.32^{\mathrm{c}}$ & $22.39 c$ & $22.41^{\mathrm{c}}$ \\
\hline $0 \%$ urea $+100 \%$ FM & $1.57^{\mathrm{d}}$ & $1.59^{\mathrm{d}}$ & $0.35^{\mathrm{d}}$ & $0.36^{\mathrm{d}}$ & $54.28^{\mathrm{e}}$ & $54.30^{\mathrm{e}}$ & $9.05^{\mathrm{e}}$ & $9.07^{\mathrm{e}}$ \\
\hline
\end{tabular}

FM, farm manure. ${ }^{\text {a-f}}$ Different letters in the same column indicate significant differences by least significant difference test at $P \leq 0.05$.

Table 5. Effect of different combinations of farm manure and urea on grain quality of wheat.

\begin{tabular}{|c|c|c|c|c|c|c|}
\hline \multirow[t]{2}{*}{ Treatments } & \multicolumn{2}{|c|}{ Protein contents (\%) } & \multicolumn{2}{|c|}{ Starch contents (\%) } & \multicolumn{2}{|c|}{ Gluten contents (\%) } \\
\hline & $2010-11$ & 2011-12 & 2010-11 & 2011-12 & 2010-11 & 2011-12 \\
\hline $0 \%$ urea $+0 \% \mathrm{FM}$ & $9.22^{\mathrm{e}}$ & $9.24^{\mathrm{e}}$ & $52.26^{\mathrm{e}}$ & $52.27^{\mathrm{f}}$ & $6.86^{\mathrm{e}}$ & $6.97^{\mathrm{e}}$ \\
\hline $100 \%$ urea + 0\% FM & $10.15^{c}$ & $10.16^{\mathrm{c}}$ & $53.65^{\mathrm{d}}$ & $53.66^{\mathrm{d}}$ & $8.49^{c}$ & $8.51^{\mathrm{c}}$ \\
\hline $75 \%$ urea + 25\% FM & $11.96^{\mathrm{a}}$ & $11.97^{\mathrm{a}}$ & $55.40^{\mathrm{a}}$ & $55.41^{\mathrm{a}}$ & $10.08^{\mathrm{a}}$ & $10.10^{\mathrm{a}}$ \\
\hline $50 \%$ urea $+50 \%$ FM & $10.98^{b}$ & $11.00^{\mathrm{b}}$ & $54.67^{\mathrm{b}}$ & $54.70^{\mathrm{b}}$ & $9.08^{b}$ & $9.10^{\mathrm{b}}$ \\
\hline $25 \%$ urea $+75 \%$ FM & $10.20^{c}$ & $10.22^{c}$ & $53.99 \mathrm{c}$ & $54.00^{c}$ & $8.91^{\mathrm{b}}$ & $8.93^{\mathrm{b}}$ \\
\hline $0 \%$ urea + 100\% FM & $9.85^{\mathrm{d}}$ & $9.86^{\mathrm{d}}$ & $52.72^{\mathrm{d}}$ & $52.73^{\mathrm{e}}$ & $7.74^{\mathrm{d}}$ & $7.75^{\mathrm{d}}$ \\
\hline
\end{tabular}

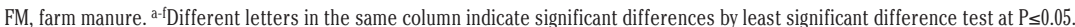

Table 6. Economic analysis and benefit cost ratio of different fertilization treatments of the experiment. Currency conversion rate are used as of 01 June 2018.

\begin{tabular}{|c|c|c|c|c|c|c|c|c|}
\hline \multirow[t]{2}{*}{ Treatments } & \multicolumn{2}{|c|}{$\begin{array}{l}\text { Total expense } \\
\left.\text { (US\$ } \mathrm{ha}^{-1}\right)\end{array}$} & \multicolumn{2}{|c|}{$\begin{array}{l}\text { Gross income } \\
\left(\text { US\$ } \mathrm{ha}^{-1}\right)\end{array}$} & \multicolumn{2}{|c|}{$\begin{array}{l}\text { Net income } \\
\left(\mathrm{US} \$ \mathrm{ha}^{-1}\right)\end{array}$} & \multicolumn{2}{|c|}{ BCR } \\
\hline & $2010-11$ & 2011-12 & $2010-11$ & $2011-12$ & $2010-11$ & $2011-12$ & 2010-11 & $2011-12$ \\
\hline $0 \%$ urea $+0 \% \mathrm{FM}$ & 999.32 & 999.32 & 1039.17 & 1028.58 & 39.85 & 29.26 & 1.04 & 1.03 \\
\hline $100 \%$ urea + 0\% FM & 1074.40 & 1074.40 & 1193.98 & 1180.30 & 119.58 & 105.90 & 1.11 & 1.10 \\
\hline $75 \%$ urea + 25\% FM & 1085.25 & 1085.25 & 1569.85 & 1579.00 & 484.59 & 493.74 & 1.45 & 1.45 \\
\hline $50 \%$ urea $+50 \%$ FM & 1086.53 & 1086.53 & 1332.03 & 1324.22 & 245.50 & 237.69 & 1.23 & 1.22 \\
\hline $25 \%$ urea $+75 \%$ FM & 1087.88 & 1087.88 & 1278.58 & 1267.73 & 190.70 & 179.85 & 1.18 & 1.17 \\
\hline $0 \%$ urea $+100 \%$ FM & 1091.16 & 1091.16 & 1137.95 & 1127.11 & 46.79 & 35.95 & 1.04 & 1.03 \\
\hline
\end{tabular}

$\mathrm{BCR}$, benefit cost ratio; FM, farm manure. 1 US $\$=121.60$ Pak Rs 


\section{Discussion and conclusions}

Nitrogen is the most important nutrient and plays an important role in growth and development of crop plants. Urea is the most common source of $\mathrm{N}$ but its use efficiency is low due to volatilization and leaching losses in nature (Engel et al., 2017). For all morphological and yield attributes, the treatment $75 \%$ urea and $25 \%$ FM produced highest values. The reason for improvement with combine application of FM and urea, might be due to overall improvement of soil properties with FM (Mohsin et al., 2012; Bedada et al., 2014). Bedada et al., (2014) reported improved soil properties and maize productivity with combine application of compost and urea relative to sole application of urea. Another reason is that farmyard manure not only improves the $\mathrm{N}$ availability but also provides micronutrient and improves use efficiency of potassium and phosphorus (Zhang et al., 2016) which results in improvement of growth and yield traits. Furthermore, FM improves water holding capacity and reduced leaching losses and thus improves nitrogen availability to the plants. Growth attributes and yield was better with sole application of urea compare to sole application of FM which is contrary to Ul-Allah et al., (2015) who reported non-significant difference in dry matter yields of fodder crops when fertilized with urea and farm yard manure. Reason might be that in case of fodder they evaluated dry matter yields while in current study grain yield is compared.

Nitrogen is an essential nutrient for the growth of plants and thus has a wide effect on the quality of wheat grains. Nitrogen uptake by the plant depicts the nitrogen use efficiency of any crop. Nitrogen uptake increased when farm manure was combined with urea at 25:75 ratio and all nitrogen attributes like nitrogen concentration in straw and grains and nitrogen uptake by the straw and grains was observed maximum. The reason is that FM has more $\mathrm{CN}$ ratio which results in immobilization of $\mathrm{N}$ (Srinivasarao et al., 2014) and in sole urea nitrogen is lost due to volatilization and leaching (Peng et al., 2015; Rech et al., 2017). FM improves soil properties which lead to the development of a higher root density and reduce leaching which in turn enhanced the nutrient-absorption capacity of the crop (Yadav, 2001). These results suggested that integrated use of organic and inorganic sources is more efficient in improving the NUE in wheat (Zhang et al., 2016). Due to improved physical conditions of the soil and greater water availability enhanced nutrient-absorption capacity of the crop (Liang et al., 2012), thereby improving biological yield at a given level of fertilizer application. Moreover, higher NUE with combination of FM and urea attributes to higher $\mathrm{N}$ availability of urea and water absorbing properties of FM, combination of which produces higher NUE.

Grain quality with respect of starch contents, crud protein, gluten contents, moisture contents and test weight improved when urea is combined with FM. Values of all quality traits were maximum at 75:25 ratios of urea and FM followed by 50:50 ratios of both. This improvement in quality is attributed to higher $\mathrm{N}$ uptake and NUE of combined application of urea and FM (Godfrey et al., 2010; Tamang et al., 2017) which is evident from the data.

In this two-year field study, regardless of sources, $\mathrm{N}$ application significantly increased the protein and gluten contents compared with control treatment. However, the integration of organic and inorganic sources gave better results compared to when they were used alone. Maximum protein and gluten contents were recorded by the application of $75 \%$ urea $25 \%$ FM compared with control treatment and decreased with increasing rate of FM and protein contents were same for treatments $100 \%$ urea $+0 \%$ FM and $25 \%$ urea $+75 \%$ FM (Table. 5). The results suggested that an adequate supply of $\mathrm{N}$ is essential to attain high wheat yield at desired protein levels. However, proper management of $\mathrm{N}$ fertilization is needed to ensure to produce high quality grain. In case of urea application it is well documented that $\mathrm{N}$ losses through volatilization results in lower $\mathrm{N}$ use efficiency of plants. The volatilization losses decrease significantly with the organic matter content and CEC of soil (Zhenghu and Honglang, 2000). Similarly, nutrients supplying capacity of organic sources are lower than the inorganic fertilizers. Therefore, our results suggested that a suitable combination of organic and inorganic sources is needed to ensure optimum supply of nutrient throughout growth cycle of wheat. Liang et al. (2013) also found that the combined application of fertilizers significantly improved the immobilization of nitrogen by fertilizer in the initial stages of wheat cultivation, when the crop demand for nutrition with nitrogen is small.

This two-year field study was conducted in the same field during both years with same agronomic practices. Due to same fertility status and weather conditions like temperature, solar radiation, humidity and rainfall (Figure 1) in both years of study, data regarding yield and related traits observed almost same trend in both years of study (Table 3).

In crux nitrogen application, either organic or inorganic and their combinations, significantly improved the productivity and grain quality of wheat; however combined application of organic and inorganic N (FM and urea) proved more beneficial than their sole applications. Combined application of FM and urea in 75:25 ratios proved best for improving productivity, grain quality and NUE of wheat.

\section{References}

AACC, 2000. Approved methods of the American association of cereal chemists, The American Association of cereal chemists, Inc. St. Paul, Minnesota.

Abid M, Schilling J, Scheffran J, Zulfiqar F, 2016. Climate change vulnerability, adaptation and risk perceptions at farm level in Punjab, Pakistan. Sci. Total Environ. 547:447-60.

Bedada W, Karltun E, Lemenih M, Tolera M, 2014. Long-term addition of compost and NP fertilizer increases crop yield and improves soil quality in experiments on smallholder farms. Agric. Ecosyst. Environ. 195:193-01.

Chupora V, 1995. Effect of green manuring crops on intensity of production-destruction processes in agro-ecosystems of central Siberia. Agrokhimiya J. 11:152-55.

Engel R, Jones C, Romero C, Wallander R, 2017. Late-fall, winter and spring broadcast applications of urea to no-till winter wheat I. Ammonia loss and mitigation by NBPT. Soil Sci. Soc. Am. J. 81:322-30.

Fageria NK, Baligar VC, Jones CA, 1997. Growth and mineral nutrition of field crops. CRC Press.

Godfrey D, Hawkesford MJ, Powers SJ, Millar S, Shewry PR, 2010. Effects of crop nutrition on wheat grain composition and end use quality. J. Agric. food chem. 58:3012-21.

Hussain M, Farooq M, Shabir G, Khan MB, Zia AB, Lee DJ, 2012. Delay in planting decreases wheat productivity. Int. J. Agric. Biol. 14:533-39.

Hussain M, Farooq S, Hasan W, Ul-Allah S, Tanveer M, Farooq M, Nawaz A, 2018. Drought stress in sunflower: Physiological effects and its management through breeding and agronomic 
alternatives. Agric. Water Manag. 201:152-66.

Hussain M, Farooq S, Jabran K, Ijaz M, Sattar A, Hassan W, 2016. Wheat sown with narrow spacing results in higher yield and water use efficiency under deficit supplemental irrigation at the vegetative and reproductive stage. Agronomy. 6:22.

Jackson M, 1962. Soil chemical analysis-Constable Ltd. London.

Jones JJB, Case VW, 1990. Sampling, handling and analyzing plant tissue samples. Sampling, handling and analyzing plant tissue samples. 3:389-27.

Khan M, Hussain I, Baloch M, Sayal O, 2001. Evaluation of wheat varieties for grain yield in DI Khan [Pakistan]. Sarhad J. Agric. 17:41-46.

Liang Q, Chen H, Gong Y, Fan M, Yang H, Lal R, Kuzyakov Y, (2012. Effects of 15 years of manure and inorganic fertilizers on soil organic carbon fractions in a wheat-maize system in the North China Plain. Nutr. Cycl. Agroecosystems. 92:21-33.

Liang B, Zhao W, Yang XY, Zhou J B, 2013. Fate of nitrogen-15 as influenced by soil and nutrient management history in a 19year wheat-maize experiment. Field Crops Res. 144:126-134.

Mohsin A, Ahmad J, Ahmad A, Ikram R, Mubeen K, 2012. Effect of nitrogen application through different combinations of urea and farm yard manure on the performance of spring maize (Zea mays L.). J. Anim. Plant Sci. 22:195-98.

Peng X, Maharjan B, Yu C, Su A, Jin V, Ferguson RB, 2015. A laboratory evaluation of ammonia volatilization and nitrate leaching following nitrogen fertilizer application on a coarse-textured soil. Agron. J. 107:871-79.

Rech I, Polidoro JC, Pavinato PS, 2017. Additives incorporated into urea to reduce nitrogen losses after application to the soil. Pesquisa Agropecuária Brasileira. 52:194-04.

Rehim A, Hussain M, Hussain S, Noreen S, DOĞAN H, Zia-UlHaq M, Ahmad S, 2016. Band-application of phosphorus with farm manure improves phosphorus use efficiency, productivity, and net returns of wheat on sandy clay loam soil. Turkish J. Agric. Forest. 40:319-26.

Sarwar G, 2005. Use of compost for crop production in Pakistan. Univ. Kassel, Fachgebiet Landschaftsökologie und Naturschutz

Satyanarayana V, Vara Prasad P, Murthy V, Boote K, 2002. Influence of integrated use of farmyard manure and inorganic fertilizers on yield and yield components of irrigated lowland rice. J. Plant Nutr. 25:2081-90.

Srinivasarao C, Venkateswarlu B, Lal R, Singh A, Kundu S, Vittal K, Patel J, Patel M, 2014. Long-term manuring and fertilizer effects on depletion of soil organic carbon stocks under pearl millet-cluster bean-castor rotation in Western India. Land Degrad. Develop. 25:173-83.

Tamang BG, Brasier KG, Thomason WE, Griffey CA, Fukao T, 2017. Differential responses of grain yield, grain protein, and their associated traits to nitrogen supply in soft red winter wheat. J. Plant Nutr. Soil Sci. 180:316-25.

Timsina J, Connor DJ, 2001. Productivity and management of rice-wheat cropping systems: issues and challenges. Field crops res. 69:93-32.

Ul-Allah S, Iqbal M, Maqsood S, Naeem M, Ijaz M, Ashfaq W, Hussain M, 2018. Improving the performance of bread wheat genotypes by managing irrigation and nitrogen under semi-arid conditions. Arch.Agron. Soil Sci. 64:1678-89.

Ul-Allah S, Khan AA, Burkert A, Wachendorf M, 2014. Socio-economic aspects of fodder production in urban and peri-urban areas of Faisalabad. Pak. J. Agric. Sci. 51:483-90.

Ul-Allah S, Khan AA, Fricke T, Buerkert A, Wachendorf M, 2015. Effect of fertiliser and irrigation on forage yield and irrigation water use efficiency in semi-arid regions of Pakistan. Exp. Agric. 51:485-00.

Yadav R, 2001. On-farm experiments on integrated nutrient management in rice-wheat cropping systems. Exp. Agric. 37:99-13.

Yazdanpanah N, Mahmoodabadi M, Cerdà A, 2016. The impact of organic amendments on soil hydrology, structure and microbial respiration in semiarid lands. Geoderma. 266:58-65.

Zhang Y, Li C, Wang Y, Hu Y, Christie P, Zhang J, Li X, 2016. Maize yield and soil fertility with combined use of compost and inorganic fertilizers on a calcareous soil on the North China Plain. Soil Till. Res. 155:85-94.

Zhao J, Ni T, Li J, Lu Q, Fang Z, Huang Q, Zhang R, Li R, Shen B, Shen Q, 2016. Effects of organic-inorganic compound fertilizer with reduced chemical fertilizer application on crop yields, soil biological activity and bacterial community structure in a rice-wheat cropping system. Appl. soil ecol. 99:1-12.

Zhenghu D and Honglang X, 2000. Effects of Soil Properties on Ammonia Volatilization. Soil Sci. Plant Nutr. 46:845-852. 